\title{
APPLICATION OF THE REFLECTIVE LEARNING THEORY IN DISCLOSURE OF STUDENT ACHIEVEMENTS WHEN LEARNING GRAMMAR II IN IAIN LANGSA.
}

Muhammad Yusuf Hasbalnikistan

alnianyusuf@gmail.com

Rita Mahriza

IAIN Langsa

ritamahriza@gmail.com

Muslem

IAIN Langsa

Moeslem.barnoeray@gmail.com

\section{ABSTRACT}

The objective of this study is to find out what are the reflection of students' achievement after learning sentences structure grammar II at IAIN Langsa.Reflection represents serious consideration of past actions and experiences with the aim to evaluate them for future actions. This research was qualitative that conducted in one class. The data has been taken by questionnaires and interviews. It is a descriptive survey research including questionnaires and interview. After collecting the data, they were analyzed and described to have the final results. The result of this thesis illustrates that there are several students' achievement reflections after learning grammar II at IAIN Langsa. There such the awareness of students of independent learning and the awareness of students about the role of students in solving a problem.

\section{Key Words}

Reflection, Reflective Learning, Grammar

\section{INTRODUCTION}

Kaplan and Rupley (2007) propose the nature and content of reflections: descriptive, dialogic, and critical reflection. Descriptive reflection 
refers to the well thought related to the desired purpose develop reasons for actions taken based on personal judgment. Dialogic reflection concerns conscious use of multiple perspectives and exploration of alternative ways to solve problems, while critical reflection considers the social, political, and or cultural forces in which teaching enterprise is situated and their impact on classroom, community, and society. Reflection is related to experience as it helps students to learn from their experiences, so it is important to explore the process of learning from the experience.

Dewey (2015) saw reflection as a specialized form of thinking. He described it as a kind of thinking that consists in turning a subject over in the mind and giving it serious thought. His definition of reflection is that it is, active, persistent and careful consideration of any belief or supposed form of knowledge in the light of the grounds that support it, and further conclusions to which it leads it, it includes a conscious and voluntary effort to establish belief upon a firm basis of evidence and rationality.

Based on this opinion, being persistent and careful in learning a subject is very important to gain evidence or clear understanding of the lesson. Therefore, students are expected to be able to learn about a subject seriously so that they can get a strong understanding of meaning.

Students' achievement reflection enables students to reflect of what they have experienced in learning process. Reflection, allows students to make connections and develop their ideas for better understanding. The students' achievement in class is one of the ways for students to understand the learning program that has completed in the end of the semester. Reflection is especially useful during education transitional level in a college, and can help students be more successful in their understanding on grammar. 
Reflection helps students to develop a deeper understanding of what they are learning through making new connections and relating different ideas.

Making new connections and developing our understanding of the lessons we have learned, we can add insight into our knowledge of these lessons. This can also help us to understand the idea of many new ideas that can be linked to other subject courses. We can use this idea to understand more about the lessons we have learned before. So that this is expected to deepen students' understanding of subjects and can improve their achievements in the future.

David Kolb (1984) is well known for his development of the Kolb cycle or cycle of experiential learning. The cycle is drawn in many different ways using different words that sometimes seem to affect its meaning. The cycle revolves with new learning undergoing active experimentation and 'recycled' through new experiencing. In this way what was a cycle becomes a spiral.

This opinion proves that there is a very important role in reflecting student understanding regarding the subjects being studied. By comparing the understanding of activities during and after learning students can gain more in-depth knowledge about how to understand a subject. Therefore, this is very suitable for us to make this become a reference in our current learning structure.

Laprad and Perkins (2014) argue that in order for reflection to be effective, it has to be intentional and systematic. Student's achievement reflection is not only consisting of their experience in learning grammar II, but also what they expect from classroom activities. The reflection is not only restricted on their competence, but also impression and suggestion. This is another challenge to face since some students still come to class with their 
instrumental motivation, to get a good grade. By examining their experience, students are expected to re-ask themselves on why they have difficult with the major and how they improve it. Thus, the students involved in this research were guided by some questionnaire to help them reflect their thought and experience.

Grammar is an inseparable part from language learning. In learning English as a foreign language, students sometimes find obstacles in comprehending the language pattern, particularly when it is different from their mother tongue. For example, the concept of different verb form in different tense is present in English, but absent in Indonesia. Teaching grammar opens challenges for teachers. Various approaches could be offered to help teachers minimize the obstacles in order to students comprehend grammar easier. However, what happens in class is the real situation. The context of student's basic knowledge and his cultural background influences the success of teaching grammar.

As one the main courses of English education at IAIN Langsa, sentence structure has been updated several times by the university with the aim of improving the performance of knowledge, particularly in English major. Therefore, there are several new courses additions to improve student accomplishment. However, the additions look to have a difference effects. One among them is, the variation that has got to be done by the university in adjusting the level stage of the course for students, as an example sentence grammar learning. The researcher wants to observe concerning student reflections once learning sentence structure grammar II. Researcher need to understand what impact they had once finishing their learning.

In conclusion, based on above explanation, the researcher expected to observe Student's achievement reflection on what they have experienced 
in learning process. The students' achievement in the class can be observed on student that has been completed the grammar II at the end of semester. Reflection helps students to develop more understanding of what they are learning through making new connections and relating different ideas. But whether the reflection of student achievement in learning sentence structure has been achieved, this needs to be observed concerning how much students understand the lesson.

\section{REVIEW OF LITERATURE}

Marton, F and Entwistle (1997) declared that one set of concept that seems to be important to unraveling the link between learning and reflection among the method of learning appear to be the research on approaches to learning. Within the sense, there is a basic distinction between student's achievement reflection with learning. This indicates that there is a possibility that there are some differences in the results that arise when learning by doing reflection and not doing so. This may be renowned through the activities distributed within the two activities. When learning, students are required to understand a course to reach a score limit. While in reflection, students are not required to reach a score limit, but rather to re-explain what results they have successfully achieved after the learning process takes place.

According to Eisner (1993) there are three ways in which reflection might be seen as relating to learning.

1. Reflection has a role in the deeper approaches to learning.

2. Learn from representing learning.

3. We upgrade learning. 
Based on the three cases above, it seems that there are some cases where students and lecturers are bound to one another in affecting learning. In the first case for example there is an understanding of deep approach learning theory that is difficult to do. In the second case, after completing the learning process, students are required to explain the understanding that has been obtained through a number of exercises in the sort of report essays and others. In the third case, the university is given the option to upgrade the learning method by creating a variety of revisions aimed toward deepening students' abilities. Based on this explanation, clearly the relevancy of the teaching strategies of a lecturer is also one of the concerns in the success of the learning process.

Another expert also gives the explanation about reflective learning, Gibbs (1998) believes that reflective learning is making a learning process into a structure that can be learned through experience. This structure creates a framework for examining experiences, and because this framework is cyclical, it is suitable for examining a person's experience, which aims to provide an opportunity for someone to plan things that are going well or not. It includes six stages namely description, feelings, evaluation, analysis, conclusions and action plans.

Grant (2007) explores the literature on reflection in the library and data sector through a scientific review. Grant found that a number of the literature on reflective practice was published in newsletters likewise as peer reviewed journals. She argues that the primary samples of reflective practice tend towards reminiscences, were largely explanatory in nature with people looking back at their career, often in a nostalgic way. 
Based on the grant's opinion, it can be explained that there were a lot of research on reflection in the world but, there were seen still very little research on reflection on world education. According to him, research on reflection has a high possibility to be able to develop into broader aspects. Moreover, research on reflection placed as a document in a library can also be an important lesson for someone to learn the results or a person's achievements through the media of experience and practice.

Tompkins' analysis (2009)demonstrates how reflections will facilitate guide internal or personal discussions around improving teaching. Tompkins argues that reflection may be a key element of the action research method, beginning with the initial determination of the issues through analyzing the results of the research. Thompkins deepens the reflective process by including a critical component that links theory and apply to the teaching sessions, that facilitate determine underlying gaps and assumptions which may be addressed in future library sessions.

In Thompkins' opinion, he seen reflection as something more special. According to him, reflection can develop further and even this can be a key to the success of a learning system. He explained that reflection is an important element in classroom action research. Because the reflection is considered to be able to coordinate important events, problems and solutions faced by a student. He believes that reflection is indeed needed in a learning system in an institution.

Schon's (1983) purposed to provide an epistemology of practice, a way of approaching practice that departs from the technical-rational epistemological model that had governed thinking in education prior to his ideas. His opposition to this instrumental approach to practice, which he feels neglects the aspect of artistry, results in his suggestion that a 
practitioner, in the face of a problem that requires more than the usual knowledge of practice. For Schon, this framing and reframing of a problem becomes the central way in which practitioners reflect. It results from reflection which takes place in unexpected situations when practitioners must reconsider previous action.

Based on Donald Schon's opinion, it seems that he centered on reflection in professional knowledge and its development. He suggested that there is a crisis within the professions associated with a misunderstanding of the relationship of theory to practice and of the type of theory that a professional use to guide their practice. The espoused theory as learnt in formal institutions and in professional training is not the speculation that proficient professionals eventually use to guide practice. They build up an expertise from their practice by being reflective. Professionals don't seem to be essentially ready to describe the idea on that they act.

In conclusion, reflective thinking and practice have a long history and have been shown to improve student achievement and facilitate independent learning. Reflection is considered to be able to help students in developing their knowledge through means of experience. Student learning experiences can help students in solving problems that are judged to be able to interfere with student understanding in completing a course in stages. Moreover, reflection is not limited to age, individual, or context, so reflection can show benefits for students in almost every case.

\section{RESEARCH METHOD}

In this study the researcher used a qualitative approach, because the problems in this study are related to the experiences of a number of people to be used as an outcome in an effort to reflect knowledge based on 
experience. Moleong (2011) argues that qualitative research is research that intends to understand phenomena about what is experienced by research subjects such as behavior, perception, motivation, actions and others holistically and by means of description in the form of words and language, in a particular context natural and by utilizing various natural methods.

Nasution (2003) argues that qualitative research is also called naturalistic research because the nature of the data collected is qualitative, not quantitative, because it does not use gauges. Called naturalistic because the research field situation is natural as it is, without being manipulated, regulated by experiment or test.

Based on the definition above explained that the qualitative approach is the approach implemented in an object, seeing the object of research as natural as possible, as is and thoroughly. Therefore, the researcher aimed to examine the research subjects carefully using survey research methods in an effort to find out the achievement results that students have achieved after learning the grammar II at IAIN Langsa.

In this research the researcher used a survey method to analyze the reflection of student's achievement in learning sentences structure grammar II at IAIN Langsa. Asmadi Alsa (2004) suggested the survey design is a procedure in which the researcher carries out a survey or provides a questionnaire or scale on one sample to describe the attitudes, opinions, behaviors, or characteristics of the respondents.

In qualitative research, survey design or method can be applied when the researcher conducted research on the reflection of student achievement about the grammar IImajor. Qualitative research with survey design can be applied to find out how students think about their understanding of grammar. This survey can be done by selecting several students who are 
sampled to explain their knowledge of grammar II.The students will be asked a several questions to reflect their thought.

Based on the opinions of the experts above, the researcher viewed that qualitative research is very appropriate to be used in the research that the researcher does. Because this research is very possible to examine the focus of the problem that the researcher examined in depth. From the results of this survey, the researcher could easily find out about what are the results of reflection on student achievement in learning grammar II.

In this study, researcher used two types of research instruments namely questionnaire and interview.

1. Questionnaire.

In this study, the researcher used questionnaire data collection techniques. According to Sugiyono (2010) questionnaire is a data collection technique by giving a set of questions or written statements to respondents to answer them. The instrument used to obtain data about students' achievement reflection in this study was a questionnaire. The reason researcher used questionnaires in this study was because he could get a clear visual of what had happened through the answers of the respondents and the benefits that students achieved after learning.

There are various types of questionnaires that can be used in conducting a study. The questionnaire that will be used by the researcher in this study is a closed questionnaire.According to Arikunto (2010), questionnaire can be divided into several types, if it is seen from the way to answer then there are:

a) Open questionnaire, which gives the opportunity for the respondent to answer in his own sentence. 
b) Closed questionnaire, which has provided the answer so that respondents just have to choose.

The instruments given to students are based on survey questionnaires which are constructed in two forms. The instrument created by the researcher depends on the content of the study. In collecting valid data, researcher used several methods such as data reduction, display data, and verification to obtain results by using a sampling survey to measure student reflection. The researcher found all the information and studied reflections carefully and deeply to find data, then researcher analyzed and interviewed a number of people to complete the research.

2. Interview.

In this research, the researcher also used an interview technique to collect the data. According to Sutrisno Hadi (1989) an interview is a verbal debriefing process, where two or more people handle physically, people can see the face of others and listen to the sound of their own ears, it turns out that direct information gathering tools on several types of social data, both hidden and manifest.

Interview method is a method of collecting data by conducting question and answer with the subject of research on the problems related to the problem that the researcher thoroughly. The type of data extracted by this method includes all the data required in the research and the source consists of experience resource of students.

According to Guba and Lincoln (1981) the interview was divided into several sections namely interviews by the team or 
panel, closed interviews and open interviews, oral interviews with interviews, structured and unstructured interviews.

In this research the researcher used semi-structured interviews, semi-structured interviews consisted of a series of predetermined questions that all interviewees answer. This kind of interview is a method of interviews where questions can be changed and broaden to find the respondents' intelligence, understanding, and experience.

In conducting research, researcher used survey methods in taking data from research subjects. With this method, researcher could easily collect the data needed through the purposive sampling method. With this sampling method, researcher could determine which students have taken the intended subject correctly. With this method, this research can be carried out and completed in a clear and detailed manner.

\section{FINDING AND DISCUSSION}

Based on the result of investigation to the subject of the study, the researcher presented the finding of the study. The data were presented based on questionnaire and interview section during study this research. The following researcher presented the findings of the study that were divided into two reflections.

The first was students' awareness of the importance of independent learning. Independent learning is an attitude of learning that prefers the search for knowledge independently. This can be done or obtained through various ways that allow someone to get an information. In this research, the researcher focused on the achievements or results 
obtained by students who have participated in learning Grammar II at IAIN Langsa.

Based on the interview section, the researcher found that there appeared to be a number of students who had difficulty understanding some of the teaching material delivered by the related lecturer. This results in student awareness of the importance of doing an independent study. But on the other hand, there were also a few students who have no difficulty in understanding the teaching material. According to them, the learning has been going well and comfortably. Here, there arise a difference in reflection from both sides of the students, who find it difficult and not. Then, what causes this difference in reflection to emerge. Here, the researcher wanted to explain how students' responses about the results they get are based on their learning experiences.

For some students who found it difficult, they thought that they were often unable to understand a number of teaching materials. This is due to the lack of references given by lecturers in delivering courses. As for the other students, they have absolutely no difficulty in this matter. In fact, they feel quite satisfied and comfortable with the results they get after participating in the learning.

According to the recognition of both students who have difficulty in understanding the course and not, they both feel happy with the grades they have received, but not with the understanding of the course. According to students who have learning difficulties, they look dissatisfied because they could not understand some material clearly. While the other students seemed uneasy about understanding the material. For them, get good grades is a satisfying result rather than understanding the material itself. 
There were two types of approaches namely surface and deep approaches. A deep approach is wherever the intention of the learner is to understand the meaning of the course, they are willing to study it concisely and understandings even reconsidering and fixing their understandings if necessary. In contrast, a surface approach to learning is wherever a learner is concerned to memorize the subject of the lesson without understanding the meaning, they are not attempting to understand it for any lasting purpose.

This illustrated that a number of students who experienced learning problems were students who understand the understanding of the deep approach that they wanted to study the course seriously to improve their English language skills through the field of grammar. While the other students, described the opposite namely the surface approach, where they only wanted to complete the course and did not wish to understand it deeply to help improve their English language skills. However, the number of students who did not experience learning difficulties was smaller, so that more students seemed appeared to reflect their awareness of the importance of independent learning.

The second reflection felt by students after learning this course is the concept of role in learning. In a learning process, there were roles of teacher and student that were interrelated with the goal of achieving a successful learning process. For example, student who has studied this lesson felt confused and did not understand the essence of a teaching material in this lesson.

In researcher's opinion, there were many aspects that could be assessed in determining the success or failure of a learning strategy in the learning process. The role is one of the elements forming a learning environment in the classroom. The role was divided into two types based 
on the subject, namely the role of teacher and student. Both have different capacities in achieving a learning success. The role of the teacher for example, according to Rusman (2016), the teacher at least has a dominant role in a learning process. There are at least four dominant roles of the lecturer in the teaching and learning process:

1. The lecturer as a demonstrator

Through his role as a demonstrator, lecturer should master the material or learning material that will be taught and develop it, because this will determine the learning outcomes achieved by students.

2. Lecturer as class managers

In its role as a classroom manager, the lecturer should be able to handle the class, because class is an environment that needs to be organized.

3. The lecturer as a mediator and facilitator

As a mediator, lecturer should have sufficient knowledge and understanding for educational media, because educational media is a communication tool to make teaching and learning processes more effective. Likewise, the lecturer as a facilitator, the teacher should be able to work on learning resources that would be useful and can support the achievement of objectives and teaching and learning process, both in the form of resource persons, textbooks, magazines, or newspapers.

4. The lecturer as an evaluator

The lecturer as a good evaluator, the lecturer should make an assessment to find out whether the goals that have been formulated are achieved or not, whether the material taught has 
been mastered or not by students, and whether the methods used are appropriate enough.

Based on the explanation above, the lecturer does have an important role in a class. It is possible to say that the lecturer is the most important element in the success of a learning process. But on the other hand, based on data obtained by the researcher during the study, there were a number of students who felt not quite satisfied with this important role. They argued that they had done everything they could to understand the course during the lesson and as a result they still could not understand the lesson.

In describing this, the researcher believed that there were several factors that could cause this to happen. It might be that there was a misunderstanding of students in understanding a course which could be in the form of student motivation, background, and culture, or there could be a mismatch in the teaching strategies of the lecturer himself. But apart from that, here the researcher found that students who experience these problems obtained an outcome or achievement of understanding the role in a learning process. Due to the problems they faced at the time, they came to understand better the roles of lecturers and students in the class. The lecturer has the duty as a facilitator and the student has the duty to follow and respect the lecturer.

In dealing with these problems, students explained they act as a group to solve their learning difficulties. They gathered with friends and expressed their opinions on these difficulties together. In addition, they also acted as a group to look for additional references from various lecturers who were studying in similar scientific fields. Acting as a group 
could help them overcome their learning difficulties while learning grammar II.

From the description above, it can be concluded that it seemed that some students experience problems while undergoing the process of learning grammar II and they overcome these problems with self-learning and cooperative learning. To overcome this problem, the subject of the study did independent learning by looking for additional references from the internet, libraries, books, and seniors to add to their insights. They also did some learning activities together or group work with their friends. Therefore, realizing the importance of the role of students in the learning process becomes the second reflection in the student's achievement in learning sentences structure of grammar II.

This is important considering that there were also a small number of students who did not seemed to want to further deepen their understanding. This is similar to the concept of understanding surfaces and deep approaches. When students wanted to deepen their ability to learn grammar II, the achievement they gained was an awareness of the importance of independent learning to deepen their understanding of a subject. Based on the theories of reflection related to learning above, the researcher got point that the reflection of student's achievement in learning is relevant to support the student's capability in understanding grammar II at IAIN Langsa.

\section{CONCLUSION}

Based on the result of research that have been done, It can be concluded that there were two conclusions. The first was student awareness of the importance of independent learning. In learning not always a course can be understood easily. Therefore, finding out about information becomes 
a very important thing for students to do in learning. Did not intend to complete a course, but also understand it in more detail and improve students' English skills. The second was realizing the importance of the role of students in the learning process. Acting as a group work could help solve students' difficulties in learning. For that reason, understanding the role of students in learning is an important effort that can be done to neutralize student misunderstanding in interpreting the essence of a course they have faced while studying grammar II at IAIN Langsa.

\section{REFERENCES}

Alsa,A.(2004).Pendekatan Kualitatif dan Kuantitatif serta Kombinasinya dalam penelitian Psikologi, Yogjakarta: Pustaka Pelajar,

Arikunto, S. (2010). Prosedur Penelitian Suatu Pendekatan Praktik, Jakarta, Rineka Cipta.

Cowan J.M. (2006). On becoming an innovative university teacher. New York: Open University Press.

Dewey, J. (2015) “'How We Think': A Restatement of the Relation of Reflective Thinking to the Educative Process." Boston Creative Education6 (4): 293.

Eisner, E. W., (1993). "Forms of understanding and the future of Educational Research,” Educational Researcher 22(7): 11.

Gibbs, G. (1998). Learning by Doing: A guide to teacbing and learning methods, UK: Further Education Unit at Oxford Polytechnic Press.

Grant, M. J. (2007). "The role of reflection in the library and information sector: A systematic review." Health Information and Libraries Journal 24: 155-166. 
Hadi, S. (1989). Metodologi Research Jilid II, Yogyakarta, Andi Offset. Lincoln, Y. S., \&Egon,G. G., (1981). Effective Evaluation. San Fransisco, Jossey Bass Publishers.

Kaplan, D.S., Rupley, W.H., Sparks, J., \& Holcomb, A. (2007). “'Comparing Traditional Journal Writing with Journal Writing Shared over E-mail List Serves as Tools for Facilitating Reflective Thinking': A Study of Preservice Teachers." Journal of Literacy Research39(3): 357-387.

LaPrade, K., Gilpatrick, M., \& Perkins, D., (2014). "Impact of Reflective Practice on Online Teaching Performance in Higher Education", MERLOT Journal of Online Learning and Teaching, 10. 625-639.

Moleong, L. J.(2011).Metodologi Penelitian Kualitatif Edisi Revisi. Bandung, PT Remaja Rosdakarya.

Nasution S. (2003)Metode Penelitian Natuarlistik Kualitatif, Bandung, Tarsito.

Schon, D. (1983). The Reflective Practitioner. How Professionals Think In Action, London: Basic BooksInc.

Sugiyono. (2010).Metode Penelitian Pendekatan Kuantitatif, Kualitatif dan R\&D, Bandung, Alfabeta.

Thompkins, E. K. (2009). "A Reflective Teaching Journal: An Instructional Improvement Tool for Academic Librarians." College and Undergraduate Libraries 16: 221-238. 